\title{
Ethanol production of semi-simultaneous saccharification and fermentation from mixture of cotton gin waste and recycled paper sludge
}

\author{
Jiacheng Shen • Foster A. Agblevor
}

Received: 30 January 2010/ Accepted: 28 May 2010/Published online: 18 June 2010

(c) The Author(s) 2010. This article is published with open access at Springerlink.com

\begin{abstract}
Ethanol production from the steam-exploded mixture of $75 \%$ cotton gin waste and $25 \%$ recycled paper sludge in various conditions was investigated by semisimultaneous saccharification and fermentation (SSSF) consisting of a pre-hydrolysis and a simultaneous saccharification and fermentation (SSF). Four cases were studied: 24-h pre-hydrolysis + 48-h SSF (SSSF 24), 12-h pre-hydrolysis + 60-h SSF (SSSF 12), 72-h SSF, and 48-h hydrolysis +24 -h fermentation (SHF). The ethanol concentration, yield, and productivity of SSSF 24 were higher than those of the other operations. A model of SSF was used to simulate the data for four components in SSF. The analysis of the reaction rates of cellobiose, glucose, cell, and ethanol using the model and the parameters from the experiments showed that there was a transition point of the rate-controlling step at which the cell growth control in the initial $2 \mathrm{~h}$ was changed to the cellobiose reaction control in later period during ethanol production of SSF from the mixture.
\end{abstract}

Keywords Simultaneous saccharification and fermentation - Enzyme hydrolysis - Kinetic model . Operating mode $\cdot$ Ethanol $\cdot$ Cotton gin waste . Recycled paper sludge

\footnotetext{
J. Shen $(\bowtie)$

Northwest Irrigation and Soils Research Laboratory, USDA, 3793 N. 3600 E., Kimberly, ID 83341, USA

e-mail: jiacheng.shen@ars.usda.gov

F. A. Agblevor

Department of Biological Systems Engineering, Virginia Polytechnic Institute and State University, Blacksburg, VA 24061, USA
}

\section{Introduction}

Cotton gin waste (CGW) and recycled paper sludge (RPS) are two residues from the cotton and paper manufacturing industries. It was estimated that about 2.04 million tons of CGW and 4 million dry tons of RPS were generated annually by the US cotton industry [1] and the papermaking industry [2], respectively. The disadvantages of traditional disposal methods for the two wastes, including landfilling, land application, and incineration [3], have been reviewed in our previous article [4]. Production of reducing sugars from carbohydrate compositions in mixtures of CGW and RPS has been reported [4, 5]. Ethanol productions from individual CGW and RPS also have been investigated by other investigators [6-11]. However, there is no publication on ethanol production from the mixture of CGW and RPS.

On the other hand, steam explosion is an effective method of pretreatment to remove hemicellulose in lignocellulosic materials and to increase the surface area of cellulose for enzymatic hydrolysis. However, it was found that some toxic compounds to fermentable microorganisms were generated during pretreatment [12, 13]. Therefore, an independent operation such as overliming is applied to eliminate the compounds. RPS contains calcium carbonate, an effective component in the overliming process. If CGW combined with RPS is pretreated by steam explosion, the toxic compounds can be eliminated, and the pretreated feedstock can be directly hydrolyzed and fermented to ethanol without other operations. The process economics of ethanol production will be improved.

Historically, two operating modes: separate hydrolysis and fermentation (SHF) and simultaneous saccharification and fermentation (SSF) have been developed for 
bioethanol production from biomass. The efficiency of operating modes for ethanol production can be evaluated using two indicators: productivity defined as the ethanol produced per unit mass of dried feedstock per unit time $(\mathrm{g} /(\mathrm{g} \mathrm{h}))$ and yield defined as the ethanol produced per unit mass of dried feedstock $(\mathrm{g} / \mathrm{g})$. SSF generally has higher productivity than SHF, because SSF has a shorter operating time. However, for the yield, there is no consentaneous conclusion on which process is better. Ohgren et al. [14] compared the yields for three cases of SSF and SHF using steam-pretreated corn stover. The two cases of SSF were better than SHF. Mishima et al. [15] observed that SSF produced higher yield and concentration of ethanol from water hyacinth and water lettuce than SHF. However, the experiments of Marques et al. [16] showed that the conversion for SHF was higher than that for SSF when they used RPS, Pichia stipitis, and Celluclast $1.5 \mathrm{~L}$ supplemented with Novozyms 188 for ethanol production.

The advantages of SSF can be attributed to its less inhibition of enzymes, and a longer time of enzymatic hydrolysis than SHF in which the enzymatic hydrolysis is ended when the substrate is separated from the hydrolysate after hydrolysis. In contrast with SSF, the advantage of SHF is its faster hydrolytic rate in optimal operating conditions than that of SSF. If a pre-hydrolysis is applied prior to SSF during which the hydrolytic rate is faster under the optimal conditions, and the substrate in the hydrolysate after hydrolysis is not removed to start SSF, the process has the advantages of both SSF and SHF. There is an optimal time to start SSF for such a combined process, which is a balance between the inhibitory and rate-controlling factors. This process can be referred to as semi-simultaneous saccharification and fermentation (SSSF), which includes a pre-hydrolytic phase and a SSF phase. Because SSSF is a process between SSF and SHF, it is expected that SSSF will have both higher productivity and yield than SSF and SHF if a suitable prehydrolytic time is selected.

The objectives of this study were:

(1) To investigate the effect of pre-hydrolysis time on ethanol productivity and yield from the mixture of CGW and RPS in SSSF operation;

(2) To investigate the effect of other factors, such as enzyme concentration (loading), substrate concentration, and severity factor, on ethanol production in SSSF operation;

(3) To apply the SSF model to the kinetic data of ethanol production from the mixture, and determine the model parameters;

(4) To investigate the rate-controlling step in SSF of ethanol production using the model.

\section{Materials and methods}

\section{Materials}

Cotton gin waste and RPS were obtained from the MidAtlantic Cotton Gin, Inc. (Emporia, VA, USA), and International Paper (Frankin, VA, USA), respectively. The CGW and RPS contained about 5-6 and 1-2 wt\% equilibrium moistures, respectively. They were thoroughly mixed to form a mixture of $75 \mathrm{wt} \%$ CGW and $25 \mathrm{wt} \%$ RPS as a substrate for ethanol production. The determination of the ratio of CGW and RPS was based on our previous study on the optimal conditions for hydrolytic experiments of the mixtures [4]. The Novozymes enzyme NS50052 used in the experiments was donated by Novozymes, North America, Inc. (Franklinton, NC). The actual activity of the enzyme examined in our laboratory by a filter paper method was 97 Filter Paper Unit (FPU)/mL [17]. The enzyme loadings used in the experiments were 21 and $42 \mathrm{FPU} / \mathrm{g}$ glucan $(=9.7$ and $19.4 \mathrm{FPU} / \mathrm{g}$ substrate, and the initial enzyme concentrations were 4 and $8 \mathrm{~mL} / \mathrm{L}$ solution). The inoculum medium for $S$. cerevisiae, which was from ATCC, was YM broth, which contained $0.3 \%$ yeast extract, $0.3 \%$ malt extract, $0.5 \%$ peptone, and $1.0 \%$ glucose. The fermentation medium contained $0.3 \%$ yeast extract, $0.25 \mathrm{~g} / \mathrm{L}$ $\left(\mathrm{NH}_{4}\right)_{2} \mathrm{HPO}_{4}$, and $0.025 \mathrm{~g} / \mathrm{L} \mathrm{M} \mathrm{MSO}_{4} 7 \mathrm{H}_{2} \mathrm{O}$.

\section{Methods}

\section{Steam-explosion pretreatment for the mixture of CGW and RPS}

The mixture of CGW (75\%) and RPS (25\%) was pretreated by steam explosion for $2 \mathrm{~min}$ at $220^{\circ} \mathrm{C}$ and $235^{\circ} \mathrm{C}$ in a 25-1 batch reactor located at the Thomas M. Brooks Forest Products Center, Blacksburg, VA, USA. The severity factors $\left(\log R_{0}\right)$ for the residence time and temperatures were calculated to be 3.83 and 4.28 , respectively, according to the concept of the reaction ordinate [18].

$$
\begin{aligned}
\log R_{0} & =\log \left[\int_{0}^{t_{\mathrm{s}}} \exp \left(\frac{T_{\mathrm{r}}-T_{\mathrm{b}}}{14.75}\right) \mathrm{d} t\right] \\
& =\log \left[t_{\mathrm{s}} \exp \left(\frac{T_{\mathrm{r}}-T_{\mathrm{b}}}{14.75}\right)\right]
\end{aligned}
$$

where $\log$ is the common logarithm based on $10, R_{0}$ is the reaction ordinate, $t_{\mathrm{s}}(\mathrm{min})$ is the residence time, $T_{\mathrm{r}}\left({ }^{\circ} \mathrm{C}\right)$ is the explosion temperature, $T_{\mathrm{b}}$ is the base temperature $\left(100{ }^{\circ} \mathrm{C}\right)$, and the number 14.75 is the constant assuming that the overall process is hydrolytic and obeys a first order kinetic law $\left({ }^{\circ} \mathrm{C}\right)$. In Eq. 1 it was assumed that the explosion temperature $T_{\mathrm{r}}$ was constant, i.e. the time for temperature 
rise could be ignored in the initial steam explosion period. The steam-exploded mixture, refereed to as pretreated whole slurry, contained about $70 \%$ moisture after the raw mixture was pretreated.

\section{Experiments of semi-simultaneous saccharification and fermentation}

Fresh colonies of $S$. cerevisiae from agar plates were inoculated in $500 \mathrm{~mL}$ Erlenmeyer flasks containing $200 \mathrm{~mL}$ YM medium with concentration $21 \mathrm{~g} / \mathrm{L}$. The cultures were grown in a shaker bath at $35{ }^{\circ} \mathrm{C}$ and $200 \mathrm{rpm}$. The cells were harvested after $18 \mathrm{~h}$, at which the optical density (OD) at $600 \mathrm{~nm}$ for the cells in the medium was $>0.35$ after 10:1 dilution. The cells were centrifuged at $6,000 \mathrm{rpm}$ for $5 \mathrm{~min}$ under sterile condition, the supernatants were removed, and the remaining solid (cells) was resuspended in $50 \mathrm{ml}$ of deionized sterile water. The washing operation was repeated three times. Finally, the cells were temporarily stored in $10 \mathrm{~mL}$ of deionized sterile water in a $-4{ }^{\circ} \mathrm{C}$ refrigerator for a couple of hours before they were utilized for the fermentation.

The SSSF experiments, which consisted of a prehydrolysis phase and a SSF phase, were conducted in a 1-L fermentor (B. Braun Biotech International, DCU3). Four cases were studied: (1) 24-h pre-hydrolysis +48 -h SSF, referred to as SSSF 24; (2) 12-h pre-hydrolysis + 60-h SSF, referred to as SSSF 12, (3) 72-h SSF, and (4) 48-h hydrolysis $+24-h$ fermentation (SHF). Each case was conducted for 72 h. 20 or 30 g (dry basis) of the pretreated whole slurry of CGW and RPS were added to the fermentor containing $0.5 \mathrm{~L}$ of citric acid buffer medium $(0.05 \mathrm{M}$, pH 4.8 ), and the fermentor was sterilized in an autoclave at $121{ }^{\circ} \mathrm{C}$ for $1 \mathrm{~h}$. After that, 2.0 or $4.0 \mathrm{~mL}$ of enzyme (the enzyme loading 21 and $42 \mathrm{FPU} / \mathrm{g}$ glucan) were added to the fermentors. In the pre-hydrolysis phase, the medium temperature and $\mathrm{pH}$ were maintained at $50{ }^{\circ} \mathrm{C}$ and 4.8 , respectively. After 24 (SSSF 24) or 12-h (SSSF 12) prehydrolysis, the medium temperature was adjusted to $36{ }^{\circ} \mathrm{C}$ and maintained at this level during the following SSF phase. When the medium temperature was reached at $36{ }^{\circ} \mathrm{C}$, the $0.15 \mathrm{~g}$ (dry weight) $S$. cerevisiae was added into the medium. The $\mathrm{pH}$ of the culture was maintained at 4.8 by automatic addition of either $2 \mathrm{M}$ hydrochloric acid or $2 \mathrm{M}$ sodium hydroxide solution during the SSF period. The agitation rate was constant at $300 \mathrm{rpm}$. Two $\mathrm{mL}$ aliquots from the broth were taken periodically and prepared for analysis as described below. The supernatant was then decanted and prepared for HPLC analysis by being filtered through a $0.2 \mu \mathrm{m}$ syringe filter. While SSF was performed, the temperature and $\mathrm{pH}$ were maintained at $36{ }^{\circ} \mathrm{C}$ and 4.8 from the start to the end of experiments. When SHF was performed, the hydrolysis was conducted at a temperature of $50{ }^{\circ} \mathrm{C}$ and $\mathrm{pH}$ of 4.8 for $48 \mathrm{~h}$, the hydrolyzed solid was separated from hydrolysate, and the yeast was added to the hydrolysate to start fermentation at a temperature of $36{ }^{\circ} \mathrm{C}$ and $\mathrm{pH}$ of 4.8 for $24 \mathrm{~h}$. The experiments were triplicate.

Analytical method

Cellobiose, glucose, ethanol, and xylose concentrations

The cellobiose, glucose, ethanol, and xylose concentrations were measured using a Shimadzu 10A HPLC instrument (Kyoto, Japan) equipped with a RI detector, an autosampler (SIL-20AC), and a carbohydrate column $(7.8 \times$ 300 mm, BP-100 H ${ }^{+}, 802$ Benson Polymeric Inc., Reno, $\mathrm{NV}$ ). The column temperature was $60^{\circ} \mathrm{C}$. Mobile phase was $0.0025 \mathrm{M} \mathrm{H}_{2} \mathrm{SO}_{4}$ with the flow rate at $0.6 \mathrm{~mL} / \mathrm{min}$. The working mode of HPLC was isocratic. The identities of the components were authenticated by comparing their retention times with those of pure compounds (SigmaAldrich, St. Louis, MO).

Acid-insoluble lignin, glucan, xylan, and ash in the raw mixture, and pretreated whole slurry

Figure 1 presents the analytical procedure of the pretreated whole slurry. The overall glucan and xylan contents $\left(P_{\mathrm{g}, \mathrm{t}}\right.$ and $\left.P_{\mathrm{x}, \mathrm{t}}\right)$ in the pretreated whole slurry derived from two parts: the glucan and xylan in the pretreated solid $\left(P_{\mathrm{g}, \mathrm{d}}\right.$ and $\left.P_{\mathrm{x}, \mathrm{d}}\right)$ and in the liquid fraction $\left(W_{\mathrm{g}, 1}\right.$ and $\left.W_{\mathrm{x}, 1}(\mathrm{~g} / \mathrm{L})\right)($ the glucose and xylose in the liquid were converted into the glucan and xylan). The contents of the acid-insoluble lignin, glucan, xylan, and ash in the pretreated solid, and the raw mixture of $75 \% \mathrm{CGW}$ and $25 \%$ RPS were determined according to ASTM E1721-95 [19] and ASTM E1755-95 [20], respectively. The glucose and xylose concentrations $\left(W_{\mathrm{g}, 1}\right.$ and $\left.W_{\mathrm{x}, 1}\right)$ of the liquid fraction of the pretreated whole slurry were measured as follows: about $1 \mathrm{~g}$ of pretreated whole slurry was suspended in $84 \mathrm{~mL}$ of deionized water, and the suspension was stirred for $30 \mathrm{~min}$ to dissolve the soluble compounds into the water. Then, the suspension was centrifuged at $6,000 \mathrm{rpm}$ for $10 \mathrm{~min}$, and the solid was separated from the liquid fraction. $3 \mathrm{~mL}$ of $72 \%$ sulfuric acid was added to the supernatant to form a $4 \%$ dilute sulfuric acid solution. The solutions were sterilized in an autoclave at $121{ }^{\circ} \mathrm{C}$ for $1 \mathrm{~h}$. The samples were analyzed for various sugars by the HPLC as described above.

To distinguish the effect of the dilute sulfuric acid (4\%) at $121{ }^{\circ} \mathrm{C}$ for $1 \mathrm{~h}$ (autoclave) from that of the concentrated sulfuric acid $(72 \%)$ at $30{ }^{\circ} \mathrm{C}$ for $1 \mathrm{~h}$ on hydrolysis of the pretreated solid in the procedure of ASTM E1721-95, some samples of the pretreated solid were directly hydrolyzed by dilute sulfuric acid as follows: the sample of the pretreated 


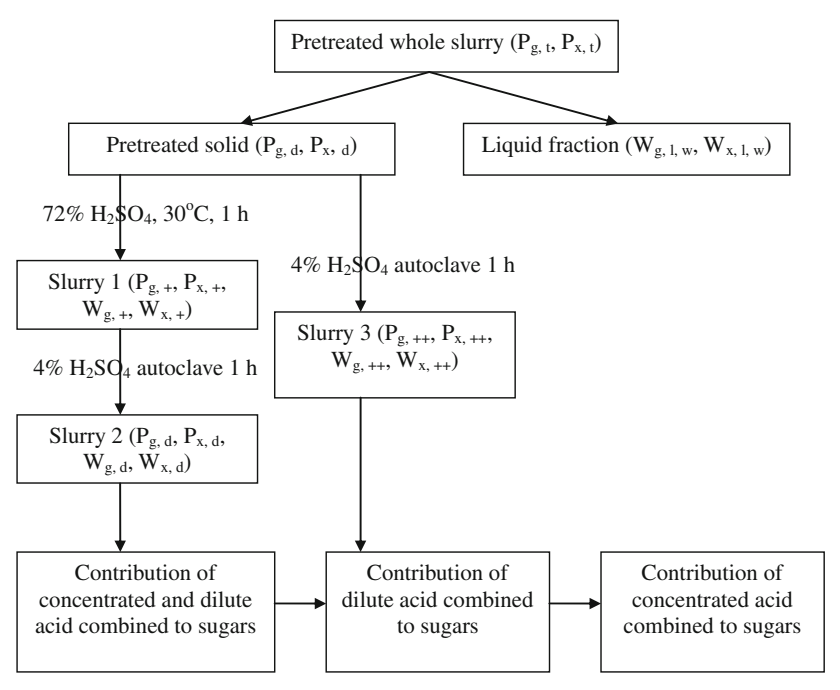

Fig. 1 Analytical procedure of the pretreated whole slurry

solid in $84 \mathrm{~mL}$ deionized water was added $3 \mathrm{~mL}$ of $72 \%$ sulfuric acid to form a $4 \%$ dilute sulfuric acid solution. The suspensions containing the solid were sterilized in the autoclave at $121{ }^{\circ} \mathrm{C}$ for $1 \mathrm{~h}$, and the glucose and xylose concentrations in the liquid were analyzed. These sugar concentrations were converted into glucan and xylan concentrations in the liquid, refereed to as $W_{\mathrm{g},++}$ and $W_{\mathrm{x},++}$ (g/L), and their contents $P_{\mathrm{g},++}$ and $P_{\mathrm{x},++}$ in the raw mixture, respectively.

\section{Results and discussion}

\section{Compositions of the mixture of CGW and RPS}

The compositions of the raw mixture of $75 \%$ CGW and $25 \%$ RPS, the pretreated solid, and the pretreated whole slurry (i.e. including the liquid fraction) with severity factor 4.28 are shown in Table 1. After pretreatment of steam explosion, the percentages of the glucan and lignin in the pretreated mixture increased from 46.2 and 23 to
47.6 and $28.7 \%$, and the percentages of the xylan and ash decreased from 8.13 and 19.4 to 5.18 and $7.17 \%$, respectively. This is because at high temperature, the xylan originally from hemicellulose in the mixtures was easily degraded by the steam explosion, and released into the liquid fraction as well as the ash composition. However, the glucan in the mixtures were more difficult to be decomposed without acid hydrolysis even at high temperature. Therefore, the percentages of glucan and lignin in the present study increased after pretreatment of steam explosion because of loss of the hemicellulose and ash in the solid fraction of the mixture. Similar observation has been reported by Jeoh and Agblevor [6]. Table 1 also shows the percentages, $P_{\mathrm{g}, \mathrm{d}}$, of glucan (or $P_{\mathrm{x}, \mathrm{d}}$ of xylan) weight in the pretreated solid to the weight, $W$, of the pretreated solid, i.e.

$P_{\mathrm{g} \text { or x }, \mathrm{d}}=\frac{W_{\mathrm{g} \text { or x } \mathrm{d}}}{W} \%$

and $P_{\mathrm{g}, \mathrm{t}}$ of overall glucan (or $P_{\mathrm{x}, \mathrm{t}}$ of overall xylan) weight, including glucan (or xylan) both in liquid and solid fractions of the pretreated whole slurry, to the weight of the pretreated solid, i.e.

$P_{\mathrm{g} \text { or } \mathrm{x}, \mathrm{t}}=\frac{W_{\mathrm{g} \text { or } \mathrm{x}, \mathrm{d}}+W_{\mathrm{g} \text { or } \mathrm{x}, 1}}{W}$

where $W_{\mathrm{g}, \mathrm{d}}$ is the concentration of glucan (or $W_{\mathrm{x}, \mathrm{d}}$ of xylan) in the pretreated solid $(\mathrm{g} / \mathrm{L}), W_{\mathrm{g}, 1}$ is the concentration of glucan (or $W_{\mathrm{x}, 1}$ of xylan) in the liquid fraction of the pretreated whole slurry $(\mathrm{g})$, and $W$ is the concentration of the pretreated solid $(\mathrm{g} / \mathrm{L})$. It was found that the contributions of glucan $(0.1 \%=47.7-47.6 \%$ in Table 1) and xylan $(0.005 \%=5.183-5.178 \%$ in Table 1$)$ in the liquid fraction of the pretreated whole slurry to the overall glucan and xylan contents of the pretreated whole slurry were very small because glucan $\left(W_{\mathrm{g}, 1, \mathrm{w}} 1.5 \mathrm{~g} / \mathrm{L}\right)$ and xylan $\left(W_{\mathrm{x}, 1, \mathrm{w}}\right.$ $10.1 \mathrm{~g} / \mathrm{L}$ ) concentrations in the liquid fraction were very low (Table 2). These values are lower than those reported for steam-pretreated corn stover [12], probably because 3\% $\mathrm{SO}_{2}$ was added to corn stover in the steam pretreatment of

Table 1 The composition of raw and pretreated mixture of 75\% CGW and 25\% RPS

\begin{tabular}{|c|c|c|c|c|c|}
\hline Composition & Glucan (\%) & Xylan $(\%)$ & Lignin $(\%)$ & Ash (\%) & Other $(\%)$ \\
\hline Dry raw CGWRPS & 46.2 & 8.13 & 23.0 & 19.4 & 3.34 \\
\hline PS & $P_{\mathrm{g}, \mathrm{d}}=47.6\left(45.3^{\mathrm{a}}, 2.28^{\mathrm{b}}\right)$ & $P_{\mathrm{x}, \mathrm{d}}=5.178\left(3.26^{\mathrm{a}}, 1.92^{\mathrm{b}}\right)$ & 28.7 & 7.17 & 11.3 \\
\hline PWS & $P_{\mathrm{g}, \mathrm{t}}=47.7$ & $P_{\mathrm{x}, \mathrm{t}}=5.183$ & 28.6 & 7.15 & 11.3 \\
\hline
\end{tabular}

$P_{\mathrm{g}, \mathrm{d}}$ and $P_{\mathrm{x}, \mathrm{d}}$ : glucan and xylan weight in the pretreated solid to the weight of the pretreated solid (Eq. 2 )

$P_{\mathrm{g}, \mathrm{t}}$ and $P_{\mathrm{x}, \mathrm{t}}$ : overall glucan and xylan weight, including glucan and xylan in liquid and solid fractions of the pretreated whole slurry, to the weight of the pretreated solid (Eq. 3)

PS pretreated solid with the severity factor 4.28 , PWS pretreated whole slurry with the severity factor 4.28

${ }^{\text {a }}$ Concentrated sulfuric acid contribution

b Diluted sulfuric acid contribution 
Table 2 The composition concentrations in the liquid fraction of the pretreated whole slurry, and in the liquid of the pretreated solid after $4 \%$ sulfuric acid treatment

\begin{tabular}{lcl}
\hline Composition & Glucan $(\mathrm{g} / \mathrm{L})$ & Xylan $(\mathrm{g} / \mathrm{L})$ \\
\hline$W_{\mathrm{g}, 1, \mathrm{w}}$ and $W_{\mathrm{x}, \mathrm{l}, \mathrm{w}}$ & 1.50 & 10.1 \\
$W_{\mathrm{g}, \mathrm{d}}$ and $W_{\mathrm{x}, \mathrm{d}}$ & 11.2 & 19.8 \\
\hline
\end{tabular}

Ohgren's experiment, which made hydrolysis more effective. Table 2 also shows the glucan and xylan concentrations in the liquid after $4 \%$ sulfuric acid treatment of the pretreated solid, $W_{\mathrm{g}, \mathrm{d}}$ and $W_{\mathrm{x}, \mathrm{d}}$ to be 11.2 and $19.8 \mathrm{~g} / \mathrm{L}$, respectively. These values can be converted into percentages $\left(P_{\mathrm{g},+}\right.$ and $\left.P_{\mathrm{x},+}\right)$ of glucan and xylan in the pretreated solid after $4 \%$ sulfuric acid treatment shown in Table 1 to distinguish between the effect of the concentrated and dilute sulfuric acids on the hydrolysis. The contributions of the concentrated sulfuric acid in decomposition of the carbohydrate fraction during hydrolysis were $95.2 \%$ $(=45.3 / 47.6 \%)$ for glucan and $63.0 \%(=3.26 / 5.178 \%)$ for xylan, while the contributions of dilute sulfuric acid were $4.8 \%(=2.28 / 47.6 \%)$ for glucan and $37.0 \%(=1.92 / 5.178 \%)$ for xylan. The greater contribution difference of glucan $(90.4 \%=95.2-4.8 \%)$ than that of xylan $(26 \%=63-27 \%)$ between the concentrated acid and dilute acid hydrolysis was because the hemicellulose (source of xylan) was easier decomposed than cellulose (source of glucan) with the dilute acid treatment (the calculation procedure in Fig. 1).

Pre-hydrolysis of cellulose and its simulation

The conversion of cellulose and the reducing sugar concentration for the pretreated whole slurry at the initial enzyme loadings of 21 and $42 \mathrm{FPU} / \mathrm{g}$ glucan (enzyme

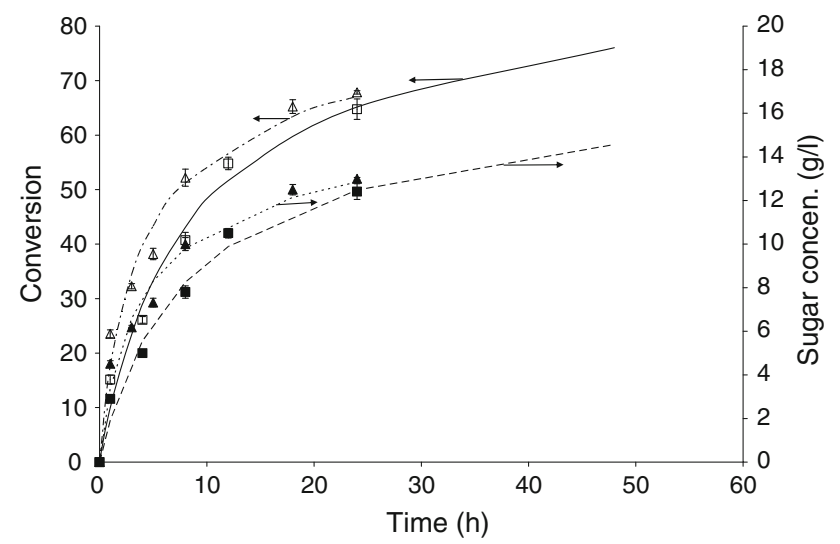

Fig. 2 The conversion of mixture and reducing sugar concentration with time in the pre-hydrolysis phase. Symbol experimental points, line model values open square, filled square: SSSF 24 at initial enzyme concentration $4 \mathrm{~g} / \mathrm{L}$, open triangle, filled triangle: SSSF 12 at initial enzyme concentration $8 \mathrm{~g} / \mathrm{L}$ concentrations 4 and $8 \mathrm{~g} / \mathrm{L}$ ) are showed in Fig. 2. The conversion and reducing sugar concentration increased with hydrolytic time. The highest conversion and reducing sugar concentration were about $64.8 \%$ and $12.5 \mathrm{~g} / \mathrm{L}$ for the initial enzyme concentration $4 \mathrm{~g} / \mathrm{L}$, and $67.9 \%$ and $12.9 \mathrm{~g} / \mathrm{L}$ for the initial enzyme concentration $8 \mathrm{~g} / \mathrm{L}$ in 24 -h hydrolysis. To correlate the conversion (or sugar concentration) with hydrolytic time, Shen and Agblevor [4] developed an enzymatic hydrolysis model with convergent property of carbohydrate conversion as follows:

The carbohydrate conversion $\mathrm{x}$ in substrate is defined as

$x=\frac{C_{0}-C_{1}}{C_{0}}=\frac{r G_{1}}{C_{0}}=1-\left[\frac{K_{e}+e_{0}}{K_{e}\left(k_{2}^{\prime} e_{0} t+1\right)+e_{0}}\right]^{b}$

where $r$ is the average conversion factor from a glucan unit in cellulose to glucose (0.9), the constant $b=\frac{k_{3}^{\prime}}{K_{e} k_{2}^{\prime}}$ (dimensionless), $k_{2}^{\prime}$ is the enzyme deactivation constant in the prehydrolysis phase $(1 /(\mathrm{g} \mathrm{h})), k_{3}^{\prime}$ is the rate constant of the sugar formation $\left(\mathrm{h}^{-1}\right)$, the constant $K_{e}=\frac{k_{-1}^{\prime}+k_{3}^{\prime}}{k_{1}^{\prime}}$ is the equilibrium constant $(\mathrm{g} / \mathrm{L}), k_{1}^{\prime}$ is the adsorption constant of enzyme on substrate $(\mathrm{L} /(\mathrm{g} \mathrm{h})), k_{-1}^{\prime}$ is the desorption constant of enzyme on substrate $\left(\mathrm{h}^{-1}\right), C_{0}$ is the initial cellulose concentration in suspension $(\mathrm{g} / \mathrm{L}), C_{1}$ is the final cellulose concentration in suspension $(\mathrm{g} / \mathrm{L}), G_{1}$ is the final glucose concentration $(\mathrm{g} / \mathrm{L})$, $e_{0}$ is the initial enzyme concentration $(\mathrm{g} / \mathrm{L})$, and $t$ is the residence time (h). When $e_{0} \rightarrow \infty, x$ converges to a constant at a constant time (Eq. 5)

$x=\frac{C_{0}-C_{1}}{C_{0}}=\frac{r G_{1}}{C_{0}}=1-\left(\frac{1}{K_{e} k_{2}^{\prime} t+1}\right)^{b}=\mathrm{constant}$

and when $t \rightarrow \infty, x$ converges to the maximum of 1 .

The curves in Fig. 2 are the simulated results for conversion and sugar concentration using Eq. 4. The parametric values of the model (Eq. 4) are shown in Table 3. The constants $K_{\mathrm{e}}, k_{2}^{\prime}$, and $k_{3}^{\prime}$ at the initial enzyme concentration $4 \mathrm{~g} / \mathrm{L}$ were smaller than those at $8 \mathrm{~g} / \mathrm{L}$. The constant $k_{2}^{\prime}$ represents the enzyme deactivation; hence, the smaller the $k_{2}^{\prime}$, the lower the enzyme deactivation. At a higher enzyme concentration, the enzyme had more chance to be adsorbed on the lignin and loses its activity. Hence, the constant $k_{2}^{\prime}$ has a larger value at a higher enzyme

Table 3 Model parameters (Eq. 4) for the mixture of 75\% CGW and $25 \%$ RPS

\begin{tabular}{llllll}
\hline$E_{0}(\mathrm{~g} / \mathrm{L})$ & $\begin{array}{l}E_{\mathrm{d}} \\
(\mathrm{FPU} / \mathrm{g} \\
\text { glucan })\end{array}$ & $\begin{array}{l}K_{\mathrm{e}} \\
(\mathrm{g} / \mathrm{L})\end{array}$ & $\begin{array}{l}k_{2}{ }^{\prime} \\
(\mathrm{L} /(\mathrm{g} \mathrm{h}))\end{array}$ & $\begin{array}{l}k_{3}{ }^{\prime} \\
\left(\mathrm{h}^{-1}\right)\end{array}$ & $b(-)$ \\
\hline 4 & 21 & 0.50 & 0.407 & 0.128 & 0.63 \\
8 & 42 & 0.838 & 0.817 & 0.275 & 0.402 \\
\hline
\end{tabular}

$E_{\mathrm{d}}$, the enzyme loading based on the dried substrate (FPU/g glucan) 
concentration. The constant $k_{3}^{\prime}$ represents the reducing sugar formation rate. At a high enzyme concentration, the constant $k_{3}^{\prime}$ became larger due to the increased sugar formation. The constant $K_{\mathrm{e}}$ represents the ratio of the rate constant of complex-consumption and the rate constant of complex-formation. The $K_{\mathrm{e}}$ value increase might result from the $k_{3}^{\prime}$ value increase.

The second phase of batch SSSF experiment and its simulation

The xylose, glucose, and ethanol concentrations with respect to time for the SSSF 24, 12, and SSF experiments at the initial enzyme concentration of $4 \mathrm{~g} / \mathrm{L}$ are shown in Figs. 3, 4 and 5, respectively. In general, the ethanol concentration rapidly increased within the first 60,44 , and $48 \mathrm{~h}$ for SSSF 24, 12, and SSF, respectively, and then slightly decreased for SSS 12 and SSF, which could be because of the formation of organic acids. For SSSF 24 and 12 the glucose concentrations gradually decreased from the initial higher values with increasing time. On the contrary, the glucose concentration in the SSF first increased because of the low cell concentration (the low ethanol production rate) and the high enzyme concentration in the initial period, which resulted in the accumulation of glucose during the initial $12 \mathrm{~h}$. For all the three cases, the glucose concentration approached zero after $36 \mathrm{~h}$. This was because the yeast grew exponentially due to the sufficient supply of growthlimiting substrate, and the glucose was quickly consumed during this period. The xylose concentrations were roughly constant after pre-hydrolysis for SSSF 24 (Fig. 3) and 12 (Fig. 4), and after $12 \mathrm{~h}$ for SSF (Fig. 5) because S. cerevisiae does not utilized pentoses. As mentioned previously, the pretreated solid of CGW and RPS contained about $70 \%$ moisture. Therefore, the yield calculation should account for the culture volume increase due to the contribution of

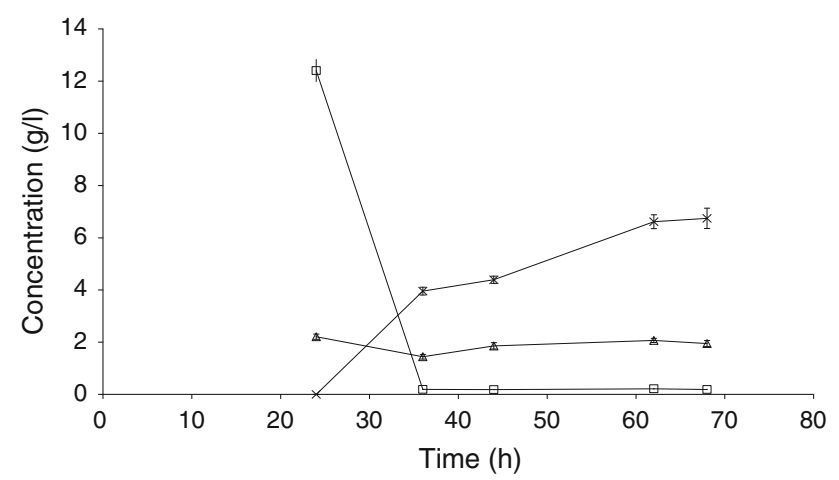

Fig. 3 The experimental points (symbols) of glucose (open squares), xylose (open triangles) and ethanol (multi symbols) concentrations with time in the batch SSSF 24. Conditions: $C_{0}=40 \times 0.479=$ $19.2 \mathrm{~g} / \mathrm{L}, X_{1}=0.3 \mathrm{~g} / \mathrm{L}, e_{0}=4 \mathrm{~g} / \mathrm{L}, G_{0}=B_{0}=E_{0}=0$, the severity factor 4.28

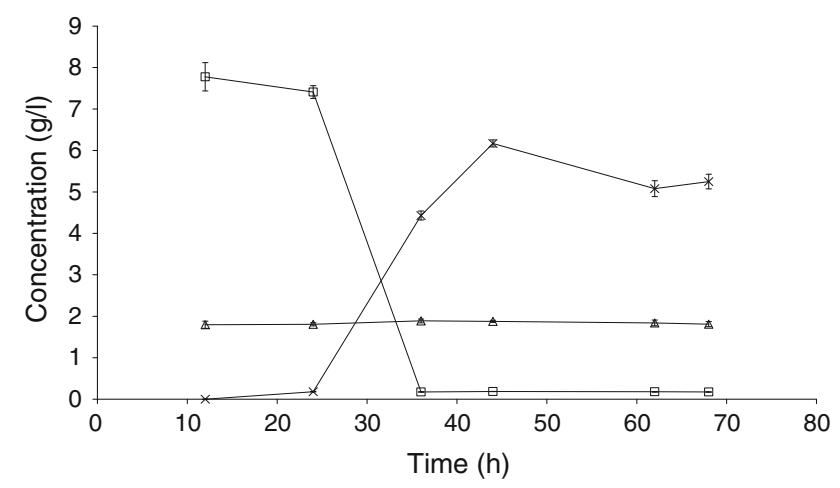

Fig. 4 The experimental points (symbols) of glucose (open squares), xylose (open triangles) and ethanol (multi symbols) concentrations with time in the batch SSSF 12. Conditions: $C_{0}=40 \times$ $0.479=19.2 \mathrm{~g} / \mathrm{L}, \quad X_{1}=0.3 \mathrm{~g} / \mathrm{L}, \quad e_{0}=4 \mathrm{~g} / \mathrm{L}, \quad G_{0}=B_{0}=E_{0}=0$, the severity factor 4.28

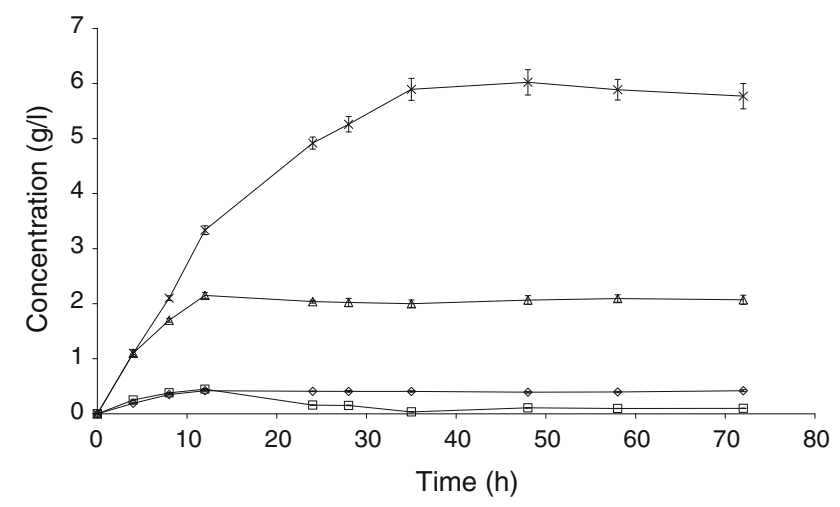

Fig. 5 The experimental points (symbols) of glucose (open squares), xylose (open triangles) ethanol (multi symbols), and cellobiose (open diamonds) concentrations with time in the batch SSF. Conditions: $C_{0}=40 \times 0.479=19.2 \mathrm{~g} / \mathrm{L}, X_{1}=0.3 \mathrm{~g} / \mathrm{L}, e_{0}=4 \mathrm{~g} / \mathrm{L}, G_{0}=B_{0}=$ $E_{0}=0$, the severity factor 4.28

water from the mixture. The actual liquid volume was $0.61 \mathrm{~L}$ for substrate concentration $40 \mathrm{~g} / \mathrm{L}$ at $0.5 \mathrm{~L}$ culture. Therefore, yield $Y$ (g ethanol/g dry substrate) should be

$Y=\frac{E V}{M}$

where $E$ is the ethanol concentration in culture $(\mathrm{g} / \mathrm{L}), V$ is the actual culture volume $(L)$, and $M$ is the substrate mass in the culture $(\mathrm{g})$. The maximum ethanol concentration for SSSF 24, 12, SSF, and SHF were 6.75, 6.17, 6.02, and $6.19 \mathrm{~g} / \mathrm{L}$, and the maximum ethanol yields were 0.206 , $0.188,0.183$, and 0.189 , respectively (Table 4 ). These yields were equal to a theoretical ethanol yield of 78.5, $71.7,69.8$, and $72.1 \%$, respectively (Table 4 ), calculated using the following equation:

$Y_{\text {th }}=\frac{0.9 Y}{0.511 G_{\mathrm{r}}} 100 \%$

where $G_{\mathrm{r}}$ is the glucan fraction in the raw mixture (Table 1). These theoretical ethanol yields were similar to 
Table 4 A comparison of yields and productivities of ethanol for SSSF, SSF, and SHF

\begin{tabular}{lcccc}
\hline Operating mode & SSSF 24 & SSSF 12 & SSF & SHF \\
\hline Theoretical yield (\%) & 78.5 & 71.7 & 69.8 & 72.1 \\
Yield (g/g substrate) & 0.206 & 0.188 & 0.183 & 0.189 \\
Productivity (g/(L h) & 0.094 & 0.086 & 0.084 & 0.086 \\
Ethanol concentration (g/L) & 6.75 & 6.17 & 6.02 & 6.19 \\
\hline
\end{tabular}

other experimental and industrial data [21, 22], but the theoretical ethanol yields of SSSF 12, SSF, and SHF were lower than the ideal yield of 76-90\%, which considered the carbon consumption for cell growth [23]. The final ethanol productivity for the SSSF 24,12 , SSF, and SHF after $72 \mathrm{~h}$ were about $0.094,0.086,0.084$, and $0.086 \mathrm{~g} /(\mathrm{L} \mathrm{h})$. The above ethanol yield, theoretical yields, and productivities show that SSSF 24 is more efficient than either SSSF 12, SSF, or SHF.

Effects of initial enzyme concentration, substrate concentration, and severity factor on the ethanol production from the mixture of CGW and RPS

Figures 5 and 6 show the glucose, xylose, and ethanol concentrations over time for SSF at two initial enzyme concentrations of 4 and $8 \mathrm{~g} / \mathrm{L}$, respectively. Because more enzyme used in Fig. 6, the ethanol concentration quickly increased to $4.7 \mathrm{~g} / \mathrm{L}$ within initial $12 \mathrm{~h}$, while the ethanol concentration in Fig. 5 at $12 \mathrm{~h}$ was only $3.3 \mathrm{~g} / \mathrm{L}$. Similar results were observed for comparisons of ethanol concentrations at $36 \mathrm{~h}$ of Fig. $3(4 \mathrm{~g} / \mathrm{L})$ and Fig. $7(5.4 \mathrm{~g} / \mathrm{L})$ for SSSF 24, and Fig. 4 (4.6 g/L) and Fig. 8 (5 g/L) for SSSF 12 at the initial enzyme concentrations of 4 and $8 \mathrm{~g} / \mathrm{L}$, respectively. However, there was no great effect of initial enzyme concentration on the final ethanol concentration because enzyme as a catalyst can increase reaction rate, but cannot change chemical equilibrium. The variations of glucose, xylose, and ethanol concentrations for SSSF 12 at the severity factor of 3.83 are shown in Fig. 9. Compared to Fig. 4 at the severity factor of 4.23 , the ethanol concentration of the former was lower than that of the latter. This indicates that the greater severity factor, (which means higher temperature in the present study), was more favorable for ethanol production. The effects of substrate concentration on ethanol SSF production are shown in Fig. 5 (at substrate concentration $40 \mathrm{~g} / \mathrm{L}$ ) and Fig. 10 (at substrate concentration $60 \mathrm{~g} / \mathrm{L}$ ). The ethanol concentrations in both figures were similar, which might result from in-perfected mixing at the high substrate concentration of $60 \mathrm{~g} / \mathrm{L}$. We observed that the agitation in the fermentor was not effective at the high substrate concentration $60 \mathrm{~g} / \mathrm{L}$. However, the theoretical yield (53.4\%) and yield (0.145 g ethanol/g

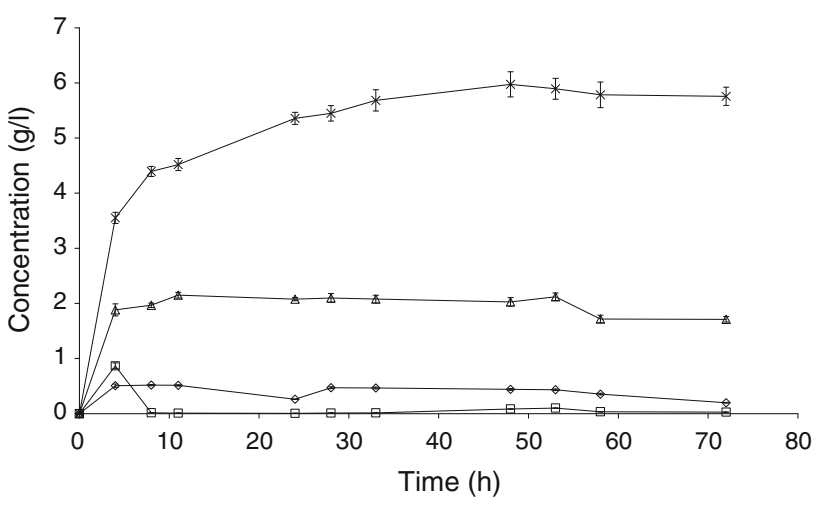

Fig. 6 The experimental points (symbols) of glucose (open squares), xylose (open triangles) ethanol (multi symbols), and cellobiose (open diamonds) concentrations with time in the batch SSF. Conditions: $C_{0}=40 \times 0.479=19.2 \mathrm{~g} / \mathrm{L}, X_{1}=0.3 \mathrm{~g} / \mathrm{L}, e_{0}=8 \mathrm{~g} / \mathrm{L}, G_{0}=B_{0}=$ $E_{0}=0$, the severity factor 4.28

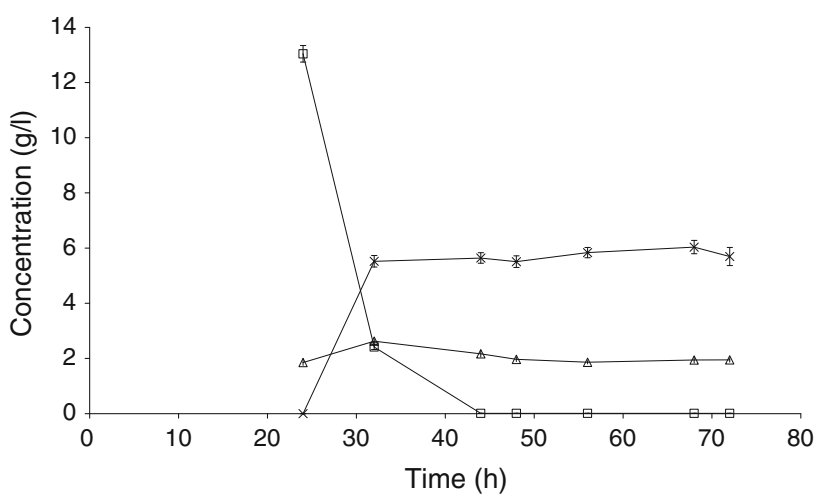

Fig. 7 The experimental points (symbols) of glucose (open squares), xylose (open triangles) and ethanol (multi symbols) concentrations with time in the batch SSSF 24. Conditions: $C_{0}=40 \times$ $0.479=19.2 \mathrm{~g} / \mathrm{L}, \quad X_{1}=0.3 \mathrm{~g} / \mathrm{L}, e_{0}=8 \mathrm{~g} / \mathrm{L}, G_{0}=B_{0}=E_{0}=0$, the severity factor 4.28

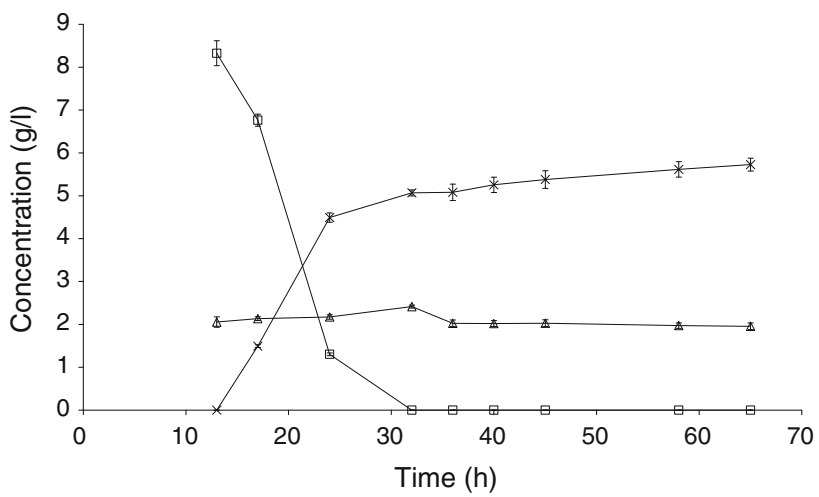

Fig. 8 The experimental points (symbols) of glucose (open squares), xylose (open triangles) and ethanol (multi symbols) concentrations with time in the batch SSSF 12 . Conditions: $C_{0}=40 \times 0.479=$ $19.2 \mathrm{~g} / \mathrm{L}, X_{1}=0.3 \mathrm{~g} / \mathrm{L}, e_{0}=8 \mathrm{~g} / \mathrm{L}, G_{0}=B_{0}=E_{0}=0$, the severity factor 4.28 


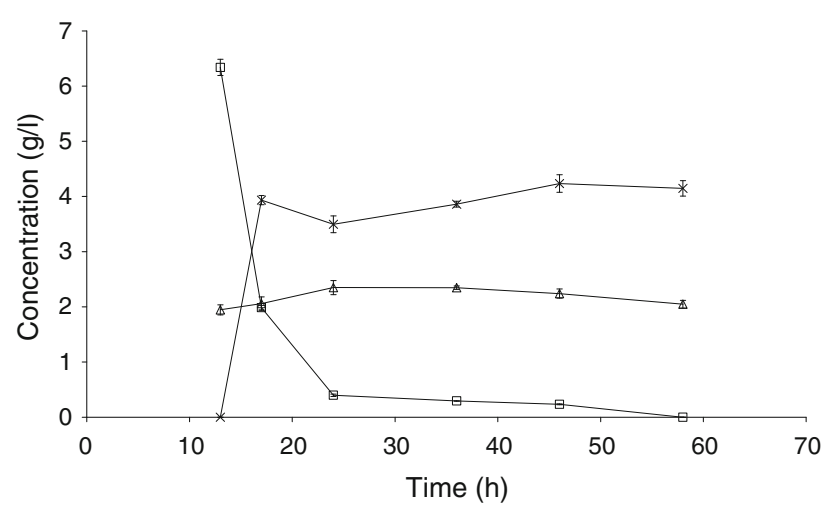

Fig. 9 The experimental points (symbols) of glucose (open squares), xylose (open triangles) ethanol (multi symbols), and cellobiose (open diamonds) concentrations with time in the batch SSSF 12. Conditions: $C_{0}=40 \times 0.479=19.2 \mathrm{~g} / \mathrm{L}, X_{1}=0.3 \mathrm{~g} / \mathrm{L}, e_{0}=4 \mathrm{~g} / \mathrm{L}, G_{0}=B_{0}=$ $E_{0}=0$, the severity factor 3.83

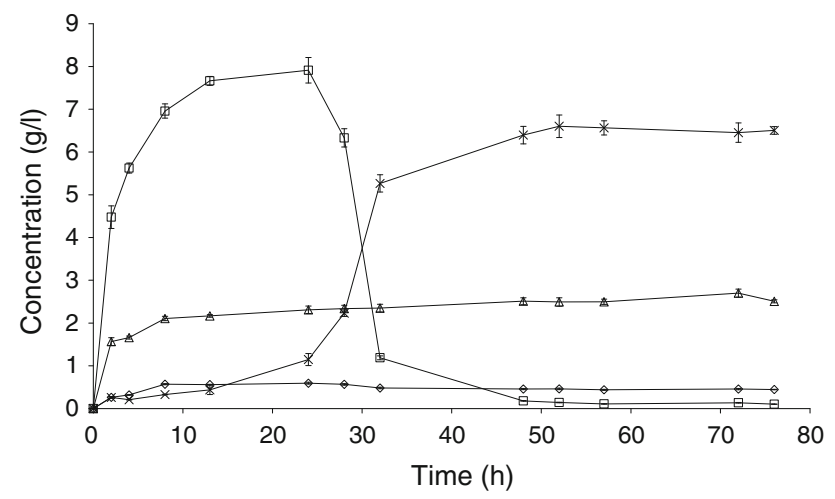

Fig. 10 The experimental points (symbols) of glucose (open squares), xylose (open triangles) ethanol (multi symbols), and cellobiose (open diamonds) concentrations with time in the batch SSF. Conditions: $C_{0}=60 \times 0.479=28.4 \mathrm{~g} / \mathrm{L}, \quad X_{1}=0.3 \mathrm{~g} / \mathrm{L}$, $e_{0}=4 \mathrm{~g} / \mathrm{L}, G_{0}=B_{0}=E_{0}=0$, the severity factor 4.28

dry substrate) for substrate concentration of $60 \mathrm{~g} / \mathrm{L}$ were lower than those for substrate concentration of $40 \mathrm{~g} / \mathrm{L}$ (67.5\% and $0.184 \mathrm{~g}$ ethanol/g substrate).

Simulation of ethanol production of SSF from the mixture of CGW and RPS

A mathematical model of SSF, which consists of four ordinary differential equations that describes the variations of four main components of cellobiose, glucose, ethanol, and cell concentrations, was developed by Shen and Aglbevor as shown follows [24]:

$$
\begin{aligned}
\frac{\mathrm{d} B}{\mathrm{~d} t}= & \frac{k_{1}\left[C_{0}-0.9 G-0.947 B-0.9 E / 0.511-1.137\left(X-X_{0}\right)\right]}{0.947\left(1+G / K_{1 \mathrm{G}}\right)} \\
& \times\left(\frac{e_{0}}{1+k_{4} e_{0} t}\right)-\frac{k_{2} B}{1+G / K_{2 \mathrm{G}}}
\end{aligned}
$$

$\frac{\mathrm{d} G}{\mathrm{~d} t}=\frac{k_{2} B}{0.95\left(1+G / K_{2 \mathrm{G}}\right)}-\frac{\mu_{m} X G}{\left(K_{\mathrm{G}}+G\right) Y_{\mathrm{X} / \mathrm{G}}}-m X$

$\frac{\mathrm{d} X}{\mathrm{~d} t}=\mu X=\frac{\mu_{m} X G}{K_{\mathrm{G}}+G}$

$\frac{\mathrm{d} E}{\mathrm{~d} t}=\frac{k_{3} \mu_{m} X G}{\left(K_{\mathrm{G}}+G\right) Y_{\mathrm{X} / \mathrm{G}}}$

where $B$ is the cellobiose concentration $(\mathrm{g} / \mathrm{L}), G$ is the glucose concentration $(\mathrm{g} / \mathrm{L}), C$ is the carbohydrate concentration in biomass $(\mathrm{g} / \mathrm{L}), e$ is the enzyme concentration $(\mathrm{g} / \mathrm{L}), k_{1}$ is the specific rate constant of cellulose hydrolysis to cellobiose $(\mathrm{L}(\mathrm{g} \mathrm{h})), k_{2}$ is the specific rate constant of cellobiose hydrolysis to glucose $\left(\mathrm{h}^{-1}\right), k_{3}$ is the product (ethanol) formation coefficient associated with cell growth (dimensionless), $k_{4}$ is the enzyme deactivation constant in $\mathrm{SSF}(\mathrm{L}(\mathrm{g} \mathrm{h})), K_{1 \mathrm{G}}$ is the inhibitory constant of glucose to the endo- $\beta$-1,4-glucanase and exo- $\beta$-1,4-cellobiohydrolase $(\mathrm{g} / \mathrm{L}), K_{2 \mathrm{G}}$ is the inhibitory constant of glucose to the glycosidase $(\mathrm{g} / \mathrm{L}), \mathrm{t}$ is the residence time $(\mathrm{h}), \mu$ is the specific cell growth rate constant $\left(\mathrm{h}^{-1}\right), \mu_{\mathrm{m}}$ is the maximum specific cell growth rate constant $\left(\mathrm{h}^{-1}\right), \mathrm{m}$ is the maintenance coefficient for endogenous metabolism of the microorganisms $\left(\mathrm{h}^{-1}\right), K_{\mathrm{G}}$ is the glucose saturation constant for the microbial growth $(\mathrm{g} / \mathrm{L}), X$ is the cell concentration $(\mathrm{g} / \mathrm{L}), Y_{\mathrm{X} / \mathrm{G}}$ is the yield coefficient of cell mass on the glucose $(\mathrm{g} / \mathrm{g}), Y_{\mathrm{G} / \mathrm{E}}$ is the conversion factor of ethanol from glucose $(\mathrm{g} / \mathrm{g}), Y_{\mathrm{X} / \mathrm{E}}$, and $Y_{\mathrm{X} / \mathrm{G}}$ are the yield coefficients of cell from ethanol, and cell from glucose $(\mathrm{g} / \mathrm{g})$, respectively, $C_{0}$ is the initial cellulose concentration $(\mathrm{g} / \mathrm{L}), X_{0}$ is the initial cell concentration $(\mathrm{g} / \mathrm{L})$, the constant 0.9 is the conversion factor of a glucan unit in cellulose to glucose, 0.947 is the conversion factor of two glucan units in cellulose to cellobiose, 0.95 is the conversion factor of cellobiose to two glucose molecules, 0.511 is the inverse conversion factor of glucose to ethanol, and 1.137 is the conversion factor of cellulose consumed to produce yeast ( $\mathrm{g}$ cellulose/g dried cell) assuming the molecular formula of the yeast, Saccharomyces cerevisiae, to be $\mathrm{CH}_{1.74} \mathrm{~N}_{0.2} \mathrm{O}_{0.45}$ during anaerobic fermentation of glucose [25].

Equations (8-11) combined with the initial conditions $C=C_{0}, e=e_{0}, X=X_{0}, G=0$, and $B=0$ at time $t=0$ can describe the concentration changes of cellobiose, glucose, cell, and ethanol with respect to time. The parameters $k_{1}, k_{2}, k_{3}, k_{4}, K_{1 \mathrm{G}}, K_{2 \mathrm{G}}$, and $\mathrm{m}$ were determined using a MATLAB fitting program (the constants $K_{\mathrm{G}}$ and $\mu_{\mathrm{m}}$ were adopted from our previous study with the similar experimental conditions [24]). These parametric values, their $95 \%$ confidence intervals (CI), and the percentages of CIs to the parametric values (PCI) are listed in Table 5, and the simulated curves are shown in Figs. 11 and 12 for the initial enzyme concentration 4 and $8 \mathrm{~g} / \mathrm{L}$, respectively. 


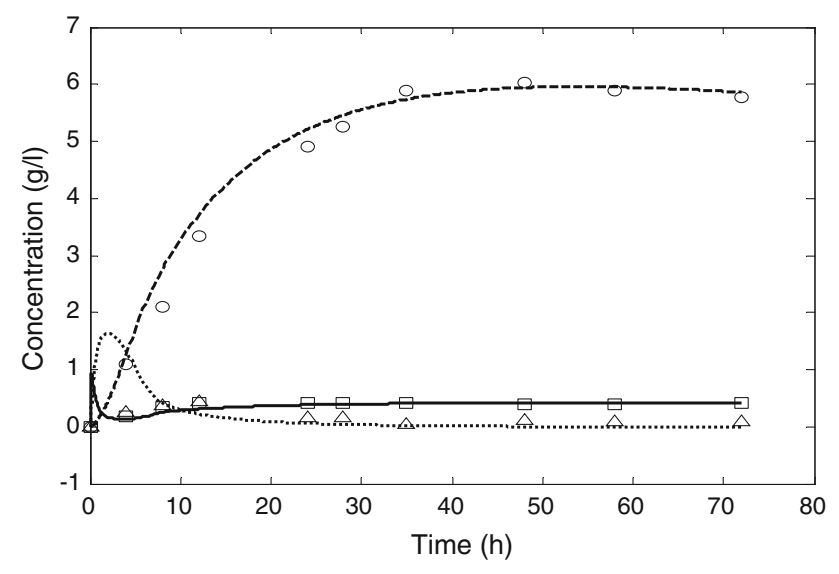

Fig. 11 The experimental points (symbols) and simulated curves (lines) of cellobiose (open squares, solid), glucose (open triangles, dot), and ethanol (open circles, dash) concentrations with time in the SSF. Conditions: $C_{0}=40 \mathrm{~g} / \mathrm{L}, X_{0}=0.3 \mathrm{~g} / \mathrm{L}, e_{0}=4 \mathrm{~g} / \mathrm{L}$, and $G_{0}=B_{0}=E_{0}=0$

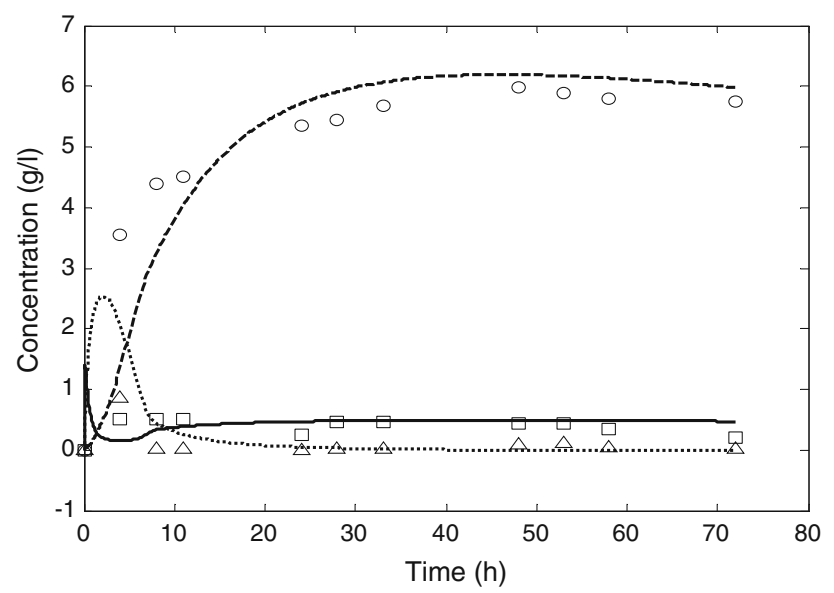

Fig. 12 The experimental points (symbols) and simulated curves (lines) of cellobiose (open squares, solid), glucose (open triangles, dot), and ethanol (open circles, dash) concentrations with time in the SSF. Conditions: $C_{0}=40 \mathrm{~g} / \mathrm{L}, X_{0}=0.3 \mathrm{~g} / \mathrm{L}, e_{0}=8 \mathrm{~g} / \mathrm{L}$, and $G_{0}=B_{0}=E_{0}=0$
From Figs. 11 and 12, we can see that the cellobiose concentration increased slightly in the later part of the SSF, which may imply that the conversion of cellobiose to glucose declined due to glycosidase deactivation. In both figures the maxima for the cellobiose concentration were lower than those of the glucose concentration, and the times for the maxima of the cellobiose were earlier than those of the glucose. This implied that the reaction from cellulose to cellobiose was a rate-controlling step because the reaction rate from cellobiose to glucose was faster than that from cellulose to cellobiose. The rate-controlling step also is demonstrated by the rate constants of each reaction since the rate constants are indicators of reaction rates when the chemical reactions have the same reaction order. The values of $k_{1} e_{0}\left(1.16 \mathrm{~h}^{-1}\right.$ for the initial enzyme concentration $4 \mathrm{~g} / \mathrm{L}$ and $2.4 \mathrm{~h}^{-1}$ for $8 \mathrm{~g} / \mathrm{L}$ ) of $r_{1}$ at the initial time were smaller than the rate constants $k_{2}\left(2.9 \mathrm{~h}^{-1}\right.$ for the initial enzyme concentration $4 \mathrm{~g} / \mathrm{L}$ and $3.0 \mathrm{~h}^{-1}$ for $8 \mathrm{~g} / \mathrm{L}$ ) (Table 5) of $r_{2}$, but were greater than $\mu=\mu_{\mathrm{m}} \mathrm{G} /$ $\left(K_{\mathrm{G}}+G\right)=0$ of $r_{\mathrm{X}}$ (Eq. 10). This indicated that initially the conversion of cellulose to ethanol was controlled by cell growth. However, the enzymatic conversion of cellulose to cellobiose would control the process as the glucose concentration increased ( $\mu$ increased) at which the values of $k_{1} e$ were less than $k_{2}$ and $\mu$.

The rate-controlling step in SSF process

Equations (8-11) are the rate expressions of cellobiose, glucose, cell, and ethanol. When the constants in these equations were determined by the MATLAB program, the reaction rates could be calculated to observe which is the rate-controlling step in SSF process. Figures 13 and 14 show the rates for SSF at the initial enzyme concentrations 4 and $8 \mathrm{~g} / \mathrm{L}$, respectively. From the figures, the reaction rates of cell and ethanol were positive because their concentrations gradually increased, while the glucose reaction rate gradually decreased from positive to negative. The cellobiose reaction rate sharply changed from a positive peak to a

Table 5 The parameter values, confidence intervals, and percentages of CIs to parametric values

\begin{tabular}{|c|c|c|c|c|c|c|c|c|c|}
\hline & $k_{1}(\mathrm{~L} /(\mathrm{g} \mathrm{h}))$ & $k_{2}\left(\mathrm{~h}^{-1}\right)$ & $k_{3}(-)$ & $k_{4} \mathrm{~L} /(\mathrm{g} \mathrm{h})$ & $K_{1 \mathrm{G}}(\mathrm{g} / \mathrm{L})$ & $K_{2 \mathrm{G}}(\mathrm{g} / \mathrm{L})$ & $K_{\mathrm{G}}(\mathrm{g} / \mathrm{L})$ & $\mathrm{m} \mathrm{h}^{-1}$ & $\mu_{\mathrm{m}}\left(\mathrm{h}^{-1}\right)$ \\
\hline \multicolumn{10}{|c|}{ Parameter $e_{0}=4 \mathrm{~g} / \mathrm{L}$} \\
\hline Value & 0.289 & 2.9 & 2.0 & 0.0243 & 0.039 & 15.9 & 3.0 & 0.69 & 0.59 \\
\hline $\mathrm{CI}( \pm)$ & 0.0128 & 0.0029 & 0.0167 & 0.0082 & 0.0042 & 0.0859 & 0.0155 & 0.0306 & 0.0132 \\
\hline PCI \% & 4.4 & 0.1 & 0.84 & 34 & 11 & 0.54 & 0.52 & 4.4 & 2.2 \\
\hline \multicolumn{10}{|c|}{ Parameter $e_{0}=8 \mathrm{~g} / \mathrm{L}$} \\
\hline Value & 0.3 & 3.0 & 1.4 & 0.02 & 0.04 & 15.0 & 3 & 0.6 & 0.6 \\
\hline $\mathrm{CI}( \pm)$ & 0.0058 & 0.0005 & 0.0010 & 0.0007 & 0.0040 & 0.0209 & 0.0047 & 0.0015 & 0.0007 \\
\hline PCI \% & 1.9 & 0.02 & 0.07 & 3.5 & 10 & 0.14 & 0.16 & 0.25 & 0.12 \\
\hline
\end{tabular}

PCI percentages of CIs to parametric values 
negative peak, because in the initial period the cellobiose reaction rate was faster due to the higher enzyme concentration. As the effective enzyme concentration decreased, the cellobiose concentration gradually decreased and the rate became negative. Within the initial $2 \mathrm{~h}$ (Figs. 13, 14), the cell growth rate controlled the entire SSF process because it had the smallest absolute reaction rate among all the absolute reaction rates. After $2 \mathrm{~h}$, the cellobiose in the figures had the smallest absolute reaction rate, which showed that the reaction from cellulose to cellobiose became the rate-controlling step in SSF process. In addition, due to the higher enzyme concentration, the reaction rates of cellobiose and glucose in Fig. 14 were faster than those in Fig. 13. For example, the peak of the glucose reaction rate for the initial enzyme concentration $8 \mathrm{~g} / \mathrm{L}$ is

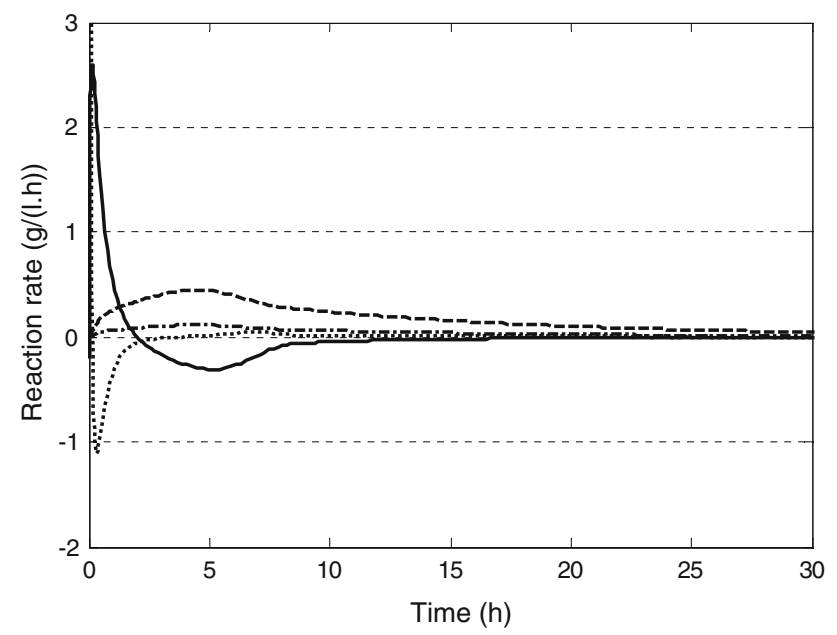

Fig. 13 The reaction rates of cellobiose (dot), glucose (solid), cell (dash-dot), and ethanol (dash) in the SSF. Conditions are the same as Fig. 11

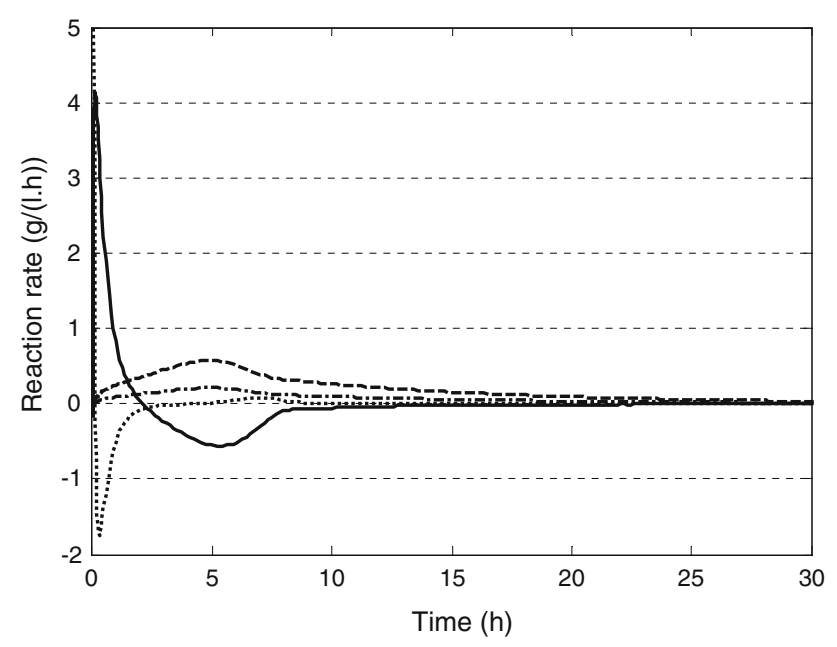

Fig. 14 The reaction rates of cellobiose (dot), glucose (solid), cell (dash-dot), and ethanol (dash) in the SSF. Conditions are the same as Fig. 12
$4.2 \mathrm{~g} /(\mathrm{L} \mathrm{h})$, while for $4 \mathrm{~g} / \mathrm{L}$, the peak of the glucose reaction rate is $2.6 \mathrm{~g} /(\mathrm{L} \mathrm{h})$.

\section{Conclusions}

Cotton gin waste and RPS, both of which contain cellulose and hemicelluloses, are the residues from the cotton and paper industries, respectively. They are potential raw materials for biofuel production. In this study, SSSF, consisting of a pre-hydrolysis and a SSF, was used to study ethanol production from the steam-exploded mixture of $75 \%$ CGW and 25\% RPS under the influencing factors of enzyme concentration, substrate concentration, and severity factor. The batch experiments showed that SSSF produced higher ethanol concentration, yield, and productivity than SSF and SHF when an optimal pre-hydrolysis time was selected. It was concluded that the higher temperature of steam explosion enhanced the ethanol concentration, but the initially higher enzyme concentration did not increase the final ethanol concentration. The SSF model, which included four ordinary differential equations for the description of concentration changes of cellobiose, glucose, microorganism, and ethanol with respect to residence time, was used to fit the experimental data for the four main components in the SSF process of ethanol production. This model showed good agreement between the experimental points and theoretical predictions. The simulation of reaction rates of four components also showed that the reaction from cellulose to cellobiose is a main rate-controlling step in SSF process.

Acknowledgments The authors acknowledge National Science Foundation (NSF) under Contract No. 0420577 and Xethanol Inc. for providing the financial support for this project.

Open Access This article is distributed under the terms of the Creative Commons Attribution Noncommercial License which permits any noncommercial use, distribution, and reproduction in any medium, provided the original author(s) and source are credited.

\section{References}

1. Holt GA, Barker GL, Baker RV, Brashears A (2000) Characterization of cotton gin byproducts produced by various machinery groups used in the ginning operation. Trans ASAE 43(6):13931400

2. Glenn J (1997) Paper mill sludge: feedstock for tomorrow. Biocycle 38(11):30-36

3. Thomasson JA (1990) A review of cotton gin trash disposal and utilization. In: Proceedings Beltwide cotton production and research conference. National Cotton Council of America, Memphis, TN, pp 689-705

4. Shen JC, Agblevor FA (2008) Optimization of enzyme loading and hydrolytic time in the hydrolysis of mixtures of cotton gin 
waste and recycled paper sludge for the maximum profit rate. Biochem Eng J 41:241-250

5. Shen JC, Agblevor FA (2008) Enzymatic hydrolytic kinetic studies of steam-exploded cotton gin waste. Chem Eng Commun 195(9):1107-1121

6. Jeoh T, Agblevor FA (2001) Characterization and fermentation of steam exploded cotton gin waste. Biomass Bioenergy 21(2):109120

7. Brink DL (1981) Making alcohol from cotton gin waste and cotton stalks. In: Proceedings of the symposium on: cotton gin trash utilization alternatives. University of California Cooperative Extension, Hanford, CA, pp 20-27

8. Beck RS, Clements DL (1982) Ethanol production from cotton gin trash. In: Proceedings of the symposium on: cotton gin trash utilization alternatives. Texas Agricultural Experiment Service, Lubock, TX, pp 163-81

9. Parnell CB, Lepori WA, Capareda SC (1991) Converting cotton gin trash into useable energy-technical and economic considerations. In: Proceedings Beltwide cotton conference, National Cotton Council of America, Memphis, TN, vol 2, pp 969-972

10. Agblevor FA, Batz S, Trumbo J (2003) Composition and ethanol production potential of cotton gin residues. Appl Biochem Biotechnol 105-108:219-230

11. Lark N, Xia YK, Qin CG, Gong CS, Tsao GT (1997) Production of ethanol from recycled paper sludge using cellulase and yeast, Kluveromyces marxianus. Biomass Bioenergy 12(2):135-143

12. Larsson S, Palmqvist E, Hahn-Hagerdal B, Tengborg C, Stenberg K, Zacchi G, Nilvebrant NO (1999) The generation of fermentation inhibitors during dilute acid hydrolysis of softwood. Enzyme Microb Technol 24(3-4):151-159

13. Ranatunga TD, Jervis J, Helm RF, McMillan JD, Wooley RJ (2000) The effect of overliming on the toxicity of dilute acid pretreated lignocellulosics: the role of inorganics, uronic acids and ether-soluble organics. Enzyme Microb Technol 27(35):240-247

14. Ohgren K, Bura R, Lesnicki G, Saddler J, Zacchi G (2007) A comparison between simultaneous saccharification and fermentation and separate hydrolysis and fermentation using steam-pretreated corn stover. Process Biochem 42(5):834-839

15. Mishima D, Kuniki M, Sel K, Soda S, Ike M, Fujita M (2008) Ethanol production from candidate energy crops: Water hyacinth (Eichhornia crassipes) and water lettuce (Pistia stratiotes L.). Bioresour Technol 99(7):2495-2500

16. Marques S, Alves L, Roseiro JC, Girio FM (2008) Conversion of recycled paper sludge to ethanol by SHF and SSF using Pichia stipitis. Biomass Bioenergy 32(5):400-406

17. Ghose TK (1987) Measurement of cellulase activities. Pure Appl Chem 59(2):257-268

18. Overend RP, Chornet E (1987) Fractionation of lignocellulosics by steam-aqueous pretreatments. Philos Trans R Soc Lond 321:523-536

19. ASTM E1721-95 (1997) Standard test method for determination of acid insoluble residues. In: Annual book of ASTM standards. American Society for Testing and Materials, West Conshohocken, PA, 11.05:1238-1240

20. ASTM E1755-95 (1997) Standard test method for determination of acid insoluble residues. In: Annual book of ASTM standards. American Society for Testing and Materials, West Conshohocken, PA, 11.05:1252-1254

21. Zhu SD, Wu YX, Zhao YF, Tu SY, Xue YP (2006) Fed-batch simultaneous saccharification and fermentation of microwave/ acid/alkali $/ \mathrm{H}_{2} \mathrm{O}_{2}$ pretreated rice straw for production of ethanol. Chem Eng Commun 193(5):639-648

22. Kosaric N, Vardar-Sukan F (2001) Potential source of energy and chemical products. In: Roehr M (ed) The biotechnology of ethanol. Wiley-VCH Verlag GmbH, Weinheim, p 180

23. Brown RC (2003) Biorenewable resources. Iowa State Press, Ames, Iowa, p 160

24. Shen JC, Agblevor FA (2010) The operable modeling of simultaneous saccharification and fermentation of ethanol production from cellulose. Appl Biochem Biotechnol 160:665-681. doi: 10.1007/s12010-009-8650-8

25. Shuler ML, Kargi F (2002) Bioprocess engineering, 2nd edn. Prentice Hall PTR, New Jersey, p 217 